\title{
Instrumen Evaluasi Karakter Mahasiswa Program Pendidikan Guru Pendidikan Anak Usia Dini
}

\author{
Wenny Hulukati ${ }^{\bowtie}$, Maryam Rahmi ${ }^{2}$ \\ Bimbingan Konseling, Universitas Negeri Gorontalo \\ DOI: $\underline{10.31004 / o b s e s i . v 4 i 2.468}$
}

\begin{abstract}
Abstrak
Berkembangnya zaman membuat individu lupa akan nilai-nilai etika di lingkungan sosial, sehingga mengalami disorientasi dan disintegrasi. Menghadapi persoalan saat ini tujuan pada penelitian adalah mengembangkan instrumen khusus untuk mengevaluasi perkembangan karakter yang terjadi pada mahasiswa/i program pendidikan guru pendidikan anak usia dini di Universitas Negeri Gorontalo. Peneltian ini menggunakan prosedur penelitian pengembangan Borg and Gall. Hasil penelitian dan pengembangan adalah: (a) telah tersusun instrumen evaluasi karakter mahasiswa yang telah melalui validasi ahli, yakni: ahli pendidikan karakter, ahli evaluasi, dan ahli bahasa Indonesia, dan (b) instrumen evaluasi karakter mahasiswa/i program pendidikan guru pendidikan anak usia dini telah melalui uji coba lapangan skala kecil. Dengan demikian instrumen evaluasi karakter mahasiswa yang merupakan hasil penelitian dan pengembangan ini telah layak digunakan, serta memberikan impak yang baik dalam membentuk karakter yang positif pada mahasiswa/i program pendidikan guru pendidikan anak usia dini.
\end{abstract}

Kata Kunci: evaluasi; instrumen karakter; pendidikan anak usia dini

\begin{abstract}
The development of the age makes individuals forget the ethical values in the social environment, so that they experience disorientation and disintegration. Facing the current problem the aim of the research is to develop a special instrument to evaluate the character development that occurs in students of early childhood education teacher education programs at Gorontalo State University. This research uses the Borg and Gall development research procedure. The results of research and development are: (a) an instrument of character evaluation has been arranged for students who have gone through expert validation, namely: character education experts, evaluation experts, and Indonesian language experts, and (b) student character evaluation instruments for child education teacher education programs early age has gone through small scale field trials. The instrument of student character evaluation which is the result of research and development is feasible to use, as well as giving a good impact in forming a positive character in students of early childhood education teacher education programs.
\end{abstract}

Keywords: evaluation; character instruments; early childhood education programs

Copyright (c) 2020 Wenny Hulukati, Maryam Rahmi

$\square$ Corresponding author:

Email Address : wennyhulukati@ung.ac.id (Gorontalo, Indonesia)

Received 15 February 2020, Accepted 17 February 2020, Published 18 February 2020 


\section{PENDAHULUAN}

Globalisasi mempunyai dampak yang menyebabkan masyarakat Indonesia mengalami degradasi karakter dan moral. Nilai-nilai leluhur yang telah lama dijunjung tinggi dan mengakar dalam perilaku bangsa Indonesia, dewasa ini cenderung mulai tergerus seirama dengan perkembangan zaman ditandai dengan disorientasi dan belum dihayatinya nilai-nilai pancasila, bergesernya nilai etika dalam berbangsa dan bernegara, memudarnya kesadaran terhadap nilai budaya, ancaman disintegrasi bangsa, serta lemahnya kemandirian bangsa telah menjadi realita yang terjadi dalam kehidupan berbangsa dan bernegara di Indonesia (Kemendiknas, 2011). Dimyati (2018) berpendapat bahwa perilaku degrasi di Indonesia saat ini ramai disoroti, sehingga disebut sebagai "penyakit sosial kronis" yang ditandai dengan perilaku kekerasan, manipulasi, konflik, korupsi, sikap yang tidak etis, berbohong, menyontek, kenakalan remaja, dan degradasi karakter yang lainnya yang menjadi pemandangan biasa dalam kehidupan masyarakat termasuk dalam institusi pendidikan di negara Indonesia ini.

Hal ini sejalan dengan pendapat Susanti (2013) bahwa terdapat fenomena sosial yang tidak berkarakter diantaranya adalah terjadinya tawuran antar pelajar/mahasiswa/desa, pergaulan bebas, kesenjangan sosial ekonomi politik di masyarakat, kerusakan lingkungan oleh masyarakat, ketidakadilan hukum, kekerasan serta kerusuhan, korupsi, tindakan anarkis oleh mahasiswa/pelajar, berkurangya nilai-nilai etika yang ada di lingkungan pendidikan. Terdapat beberapa khasus lain dimana seorang pendidik melakukan tindak pelecehan terhadap siswa. Salah satunya khasus yang terjadi di Daerah Istimewa Yogyakarta oleh guru sekaligus wali kelas para siswi yang melakukan pelecehan seksual. Kronologi ini merupakan hal yang sangat tidak wajar dilakukan oleh seorang guru. Sebagaimana guru adalah guguh dan ditiru. Selain mengajarkan siswa-siswi supaya memiliki pengetahuan dan keterampilan dalam bidang pembelajaran, tugas seorang guru adalah membentuk karakter yang baik. Kejadian ini justru berbanding terbalik dengan tugas utama sebagai guru.

Sebagai mahasiwa/i program pendidikan guru pendidikan anak usia dini atau calon guru harus memiliki pemahaman yang cukup dalam menjalankan tugas sebagai seorang calon pendidik (Brownlee et al., 2001; Buehl \& Alexander, 2001; Mischo et al., 2013; Rodríguez \& Cano, 2006). Apalagi calon guru PAUD harus memberikan contoh yang baik untuk anak usia dini, karena perkembangan dan pertumbuhan pada anak usia dini terjadi pada usia 0-6 tahun (Fika et al., 2019; Nuraeni et al., 2019). Anak akan mencontoh, melihat, atau mengcopy semua hal yang dilihat oleh anak baik itu perilaku baik atau buruk, kemudian menjadi kebiasaan untuk anak (Isikoglu, 2008; Tanto et al., 2019; Veziroglu-Celik \& Acar, 2018). Sebelum mendidik pribadi anak, seharusnya calon guru harus memiliki karakteristik pribadi yang baik dan positif (Maiza \& Nurhafizah, 2019; Srianita et al., 2019). Jika pribadi tersebut diimplementasikan pada anak, maka anak juga mencontohkan kebaikan guru tersebut. Untuk itu, sebagai calon guru PAUD mahasiswa/i harus mampu memiliki karakter yang baik dan positif, sehingga karakter tersebut dapat diterapkan dalam proses pembalajaran di kelas.

Karakter merupakan suatu pondasi bagi bangsa Indonesia yang sangat penting dan perlu ditanamkan sejak usia dini sampai tingkat perguruan tinggi yang diterapkan di lingkungan masyarakat nantinya (Mei-Ju et al., 2014; Susanti, 2013). Karakter seseorang tumbuh dan berkembang dalam konteks lingkungan, dalam arti karakter dipengaruhi oleh lingkungan di mana individu hidup. Sebagaimana dikemukakan oleh Ghufron (2012) bahwa karakter bersifat kontekstual dan kultural. Dalam konteks perkembangan individu, lingkungan dapat diklasifikasi atas lingkungan alam/lingkungan non sosial (cuaca, iklim, kondisi geografis daerah), dan lingkungan sosial (keluarga, sekolah, dan masyarakat). Dengan demikian lingkungan sekolah merupakan salah satu faktor yang dapat mempengaruhi perkembangan individu/siswa, termasuk perkembangan karakter. Di samping itu, faktor dari dalam diri individu juga turut mempengaruhi perkembangan karakter, seperti motivasi untuk memiliki karakter yang baik, kemauan untuk memperbaiki 
diri. Menurut Raka (2011) terdapat beberapa kebiasaan baik sebagai indikator kekuatan karakter, yaitu: (a) kejujuan, (b) rasa tanggung jawab, (c) semangat belajar, (d) disiplin diri, (e) kegigihan, (f) apresiasi terhadap kebhinekaan, (g) semangat berkontribusi, dan (h) optimisme.

Majid et al., (2014) Karakter yang dimiliki oleh seorang calon guru adalah karakter yang baik mengacu pada kualitas guru seperti sifat mental dan etika yang komplek yang dipengaruhi dengan nilai-nilai. Enam karakter yang harus dimiliki seorang guru adalah kebijaksanaan, dan pengetahuan, keberanian, kemanusiaan, keadilan, kesederhanaan, dan transendensi. Kebijaksanaan dan pengetahuan, meliputi: krativitas, keingintahuan, keterbukaan pikiran, cinta akan pembelajaran, dan perspektif yang bijak. Keberanian, meliputi: orang pemberani, ketekunan, menunjukkan integritas dan vitalias. Kemanusiaan, meliputi: mengacu pada cinta, kebaikan, kedermawaan, pengasuhan, perawatan, kasih sayang, cinta altruistik. Rasa keadilan, meliputi: kepemimpinan, keadilan, kewarganegaraan.

Terdapat beberapa penelitian mengenai evaluasi instrumen karakter seperti penelitian Kurdi (2018) yang berjudul evaluasi implementasi desain pendidikan karakter berbasis pendekatan humanistik. Hasil penelitian menunjukkan bahwa berbasis perkuliahan pendidikan karakter berbasis pendekatan humanistik yang dirancang memiliki peningkatan nilai dan sikap berbasis humanistik dalam diri mahasiswa sebesar $40 \%$ menjadi $75 \%-89 \%$ sebelumnya mendapatkan persentase 35-63\%. Menggunakan metode penelitian kualitatif dan subjek penelitian mahasiswa jurusan Pendidikan Guru Madrasah Ibtidaiyah Universitas Islam Antasari Banjarmasin pada mata kuliah pendidikan karakter. Sedangkan penelitian yang dilakukan adalah pengembangan instrumen evaluasi karakter untuk mahasiswa/i program Pendidikan Anak Usia Dini di Universitas Negeri Gorontalo.

Berdasarkan permasalahan yang terjadi peneliti mengembangkan instrumen evaluasi mahasiswa/i program pendidikan guru pendidikan anak usia dini. Tujuan penelitian ini untuk membentuk karakter mahasiswa/i yang mempunyai nilai-nilai etika yang baik sebelum menjadi pendidik di pendidikan anak usia dini. Instrumen evaluasi karakter yang akan disusun adalah instrumen dalam bentuk angket, yang digunakan sebagai instrumen dalam mengevaluasi perkembangan karakter mahasiswa/i program pendidikan guru pendidikan anak usia dini. Instrumen yang dikembangkan meliputi 6 (enam) indikator karakter, yakni: kejujuran, tanggung jawab, disiplin diri, kegigihan, apresiasi terhadap kebhinekaan, dan semangat berkontribusi.

\section{METODOLOGI}

Penelitian ini menggunakan prosedur penelitian pengembangan menurut Borg \& Gall (1983) yang terdiri dari 5 langkah pokok, yaitu: (1) analisis produk awal yang akan dikembangkan, (2) mengembangkan produk awal, (3) validasi ahli dan revisi, (4) uji coba lapangan skala kecil dan revisi produk, dan (5) uji coba lapangan skala besar dan produk akhir. Berikut ini langkah-langkah yang digunakan dalam penelitian.

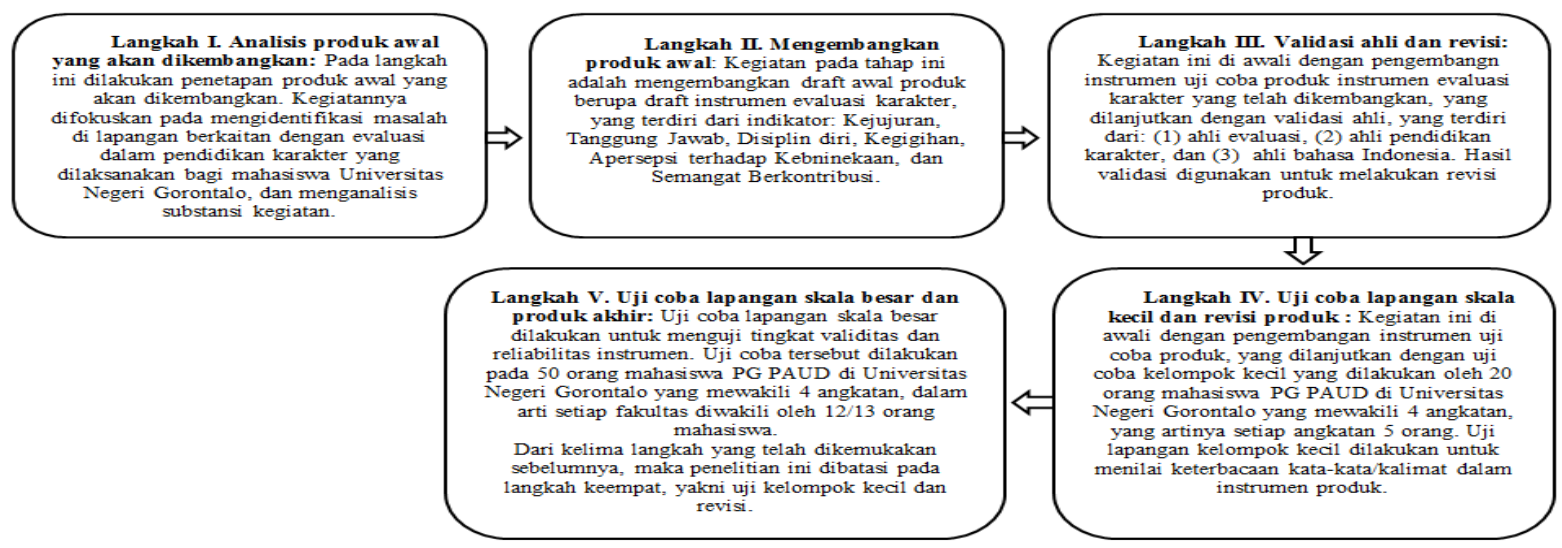

Gambar 1. Langkah Pokok Penelitian Pengembangan Borg and Gall (1983) 
Dari kelima langkah yang telah dikemukakan sebelumnya, maka penelitian ini dibatasi pada langkah keempat, yakni uji kelompok kecil dan revisi. Subyek penelitian terdiri dari: (a) 3 (tiga) orang ahli/ pakar, yakni ahli pendidikan karakter, ahli evaluasi, dan ahli bahasa Indonesia, (b) 20 orang mahasiwa Program Pendidikan Guru Pendidikan Anak Usia Dini di Universitas Negeri Gorontalo yang mewakili tiga angkatan tahun 2019/2020, 2018/2019, 2017/2018, 2016/2017 sebagai subyek uji coba lapangan kelompok kecil. Pengumpulan data dilakukan dengan: (a) Validasi pakar menggunakan angket validasi pakar, (b) Uji coba lapangan menggunakan angket. Teknik analisis data yang digunakan berupa analisis kualitatif dan kuantitatif. Analisis kualitatif digunakan untuk menganalisis data temuan hasil validasi ahli dan data uji coba skala kecil dan skala besar. Analisis kuantitatif yang digunakan menemukan tingkat validitas dan reliabilitas instrumen.

\section{HASIL DAN PEMBAHASAN}

Hasil penelitian dan pengembangan yang telah dilakukan yaitu pada langkah I analisis produk awal yang akan dikembangkan adalah penetapan produk awal yang akan dikembangkan. Kegiatannya difokuskan pada mengidentifikasi masalah di lapangan berkaitan dengan evaluasi dalam pendidikan karakter yang dilaksanakan bagi mahasiswa Universitas Negeri Gorontalo, dan menganalisis substansi kegiatan. Berdasarkan data awal, ditemukan belum ada instrumen untuk mengevaluasi perkembangan karakter mahasiswa/i program pendidikan guru pendidikan anak usia dini di Universitas Negeri Gorontalo. Berbagai kegiatan pembinaan karakter yang dilaksanakan oleh Pusat Pelatihan dan Pengembangan Karakter (PUSPENDIR) Universitas Negeri Gorontalo yang dibina oleh Jurusan Bimbingan dan Konseling tidak diiringi dengan evaluasi secara khusus dengan menggunakan instrumen evaluasi karakter. Evaluasi dilakukan pada akhir kegiatan melalui tahap refleksi di akhir kegiatan, sehingga perkembangan karakter mahasiswa tidak dapat diketahui dengan pasti.

Selanjutnya pada langkah II mengembangkan produk awal dengan melakukan mengembangkan draft awal produk berupa draft instrumen evaluasi karakter, yang terdiri dari indikator: (a) kejujuran, (b) tanggung jawab, (c) disiplin diri, (d) kegigihan, (e) apresiasi terhadap kebninekaan, dan (f) semangat berkontribusi.

Pada langkah III yaitu Validasi ahli dan revisi. Kegiatan ini di awali dengan pengembangan instrumen uji coba produk instrumen evaluasi karakter yang telah dikembangkan, yang dilanjutkan dengan validasi ahli, yang terdiri dari: (1) ahli pendidikan karakter, (2) ahli evaluasi, dan (3) ahli bahasa Indonesia. Hasil validasi digunakan untuk melakukan revisi produk. Langkah III ini telah menghasilkan: (1) draft instrumen evaluasi karakter mahasiswa yang terdiri dari 6 (enam) instrumen evaluasi, sesuai dengan indikator karakter, yakni: (a) kejujuran, (b) tanggung jawab, (c) disiplin diri, (d) kegigihan, (e) apresiasi terhadap kebhinekaan, dan (f) semangat berkontribusi; dan (2) skala penilaian yang digunakan oleh validator, yang terdiri dari: (a) skala penilaian ahli pendidikan karakter, (b) skala penilaian ahli evaluasi, dan (c) skala penilaian ahli bahasa Indonesia.

Setelah draft instrumen evaluasi karakter, dan skala penilaian ahli tersusun, maka kegiatan dilanjutkan dengan validasi ahli pendidikan karakter berupa penilaian kuantitatif dan kualitatif pada instrument evaluasi karakter mahasiswa/i program pendidikan guru pendidikan anak usia dini di Universitas Negeri Gorontalo. 
Tabel 1. Data Validasi Ahli Pendidikan Karakter

\begin{tabular}{|c|c|c|c|}
\hline No. & Aspek yang Dinilai & Nilai & Kategori \\
\hline \multirow[t]{3}{*}{ A. } & Indikator: Kejujuran & & \\
\hline & 1. Kesesuaian item-item instrumen dengan indikator: kejujuran & 7 & Baik \\
\hline & $\begin{array}{l}\text { 2. Kecukupan item-item instrumen dalam menilai kejujuran } \\
\text { mahasiswa }\end{array}$ & 8 & Sangat Baik \\
\hline \multirow{3}{*}{ B. } & Indikator: Tanggung Jawab & & \\
\hline & $\begin{array}{l}\text { 3. Kesesuaian item-item instrumen dengan indikator: tanggung } \\
\text { jawab }\end{array}$ & 8 & Sangat Baik \\
\hline & $\begin{array}{l}\text { 4. Kecukupan item-item instrumen dalam menilai tanggung } \\
\text { jawab mahasiswa }\end{array}$ & 8 & Sangat Baik \\
\hline \multirow[t]{3}{*}{ C. } & Indikator: Disiplin Diri & & \\
\hline & $\begin{array}{l}\text { 5. Kesesuaian item-item instrumen dengan indikator: disiplin } \\
\text { diri }\end{array}$ & 9 & Sangat Baik \\
\hline & $\begin{array}{l}\text { 6. Kecukupan item-item instrumen dalam menilai disiplin diri } \\
\text { mahasiswa }\end{array}$ & 8 & Sangat Baik \\
\hline \multirow[t]{3}{*}{$\mathbf{D}$} & Indikator: kegigihan & & \\
\hline & $\begin{array}{l}\text { 7. Kesesuaian item-item instrumen dengan indikator: } \\
\text { kegigihan }\end{array}$ & 9 & Sangat Baik \\
\hline & $\begin{array}{l}\text { 8. Kecukupan item-item instrumen dalam menilai kegigihan } \\
\text { mahasiswa }\end{array}$ & 8 & Sangat Baik \\
\hline \multirow[t]{3}{*}{ E. } & Indikator: Apresiasi terhadap Kebhinekaan & & \\
\hline & $\begin{array}{l}\text { 9. Kesesuaian item-item instrumen dengan indikator: apresiasi } \\
\text { terhadap kebhinekaan }\end{array}$ & 9 & Sangat Baik \\
\hline & $\begin{array}{l}\text { 10. Kecukupan item-item instrumen dalam menilai apresiasi } \\
\text { terhadap kebhinekaan mahasiswa }\end{array}$ & 9 & Sangat Baik \\
\hline \multirow[t]{4}{*}{ F. } & Indikator: Semangat Berkontribusi & & \\
\hline & $\begin{array}{l}\text { 11. Kesesuaian item-item instrumen dengan indikator: semangat } \\
\text { berkontribusi }\end{array}$ & 10 & Sangat Baik \\
\hline & $\begin{array}{l}\text { 12. Kecukupan item-item instrumen dalam menilai semangat } \\
\text { berkontribusi mahasiswa }\end{array}$ & 9 & Sangat Baik \\
\hline & Rata-Rata & 8,5 & Sangat Baik \\
\hline
\end{tabular}

Tabel 2. Saran Ahli Pendidikan Karakter

\begin{tabular}{ccl}
\hline No. & \multicolumn{1}{c}{ Saran } & \multicolumn{1}{c}{ Pertimbangan } \\
\hline 1. & $\begin{array}{l}\text { Item-item untuk indikator disiplin diri sebaiknya } \\
\text { jangan hanya fokus pada disiplin dalam belajar, }\end{array}$ & Perlu diperbaiki item-item yang lebih \\
namun disipilin diri secara umum. & fokus disiplin belajar. \\
2. & $\begin{array}{l}\text { Item nomor } 3 \text { pada indikator kegigihan sebaiknya } \\
\text { terkait dengan masalah hidup pada umumnya, }\end{array}$ & Perlu diperbaiki item nomor 3 pada \\
dalam arti jangan dibatasi pada masalah perkuliahan. & \\
3. $\begin{array}{l}\text { Pertanyaan yang terkait dengan kejujuran perlu } \\
\text { dihindari pertanyaan langsung seperti pertanyaan } \\
1,2,3,4\end{array}$ & Perlu diperbaiki sesuai saran. \\
\hline
\end{tabular}

Setelah diperoleh data hasil validasi ahli pendidikan karakter, maka kegiatan selanjutnya menggunakan data tersebut untuk melakukan revisi terhadap draft instrumen evaluasi karakter mahasiswa. Berikut ini tabel revisi data validasi ahli pendidikan karakter. 
Tabel 3. Revisi Berdasarkan Data Validasi Ahli Pendidikan Karakter

\begin{tabular}{|c|c|c|c|c|}
\hline \multirow{2}{*}{ No. } & \multirow{2}{*}{ Aspek yang Dinilai } & \multirow{2}{*}{ Nilai } & \multicolumn{2}{|c|}{ Revisi } \\
\hline & & & Ya & Tidak \\
\hline \multirow[t]{3}{*}{ A. } & Indikator: Kejujuran & & & \\
\hline & $\begin{array}{l}\text { 1. Kesesuaian item-item instrumen dengan indikator: } \\
\text { kejujuran }\end{array}$ & 7 & $\sqrt{ }$ & \\
\hline & $\begin{array}{l}\text { 2. Kecukupan item-item instrumen dalam menilai kejujuran } \\
\text { mahasiswa }\end{array}$ & 8 & & $\sqrt{ }$ \\
\hline \multirow[t]{3}{*}{ B. } & Indikator: Tanggung Jawab & & & \\
\hline & $\begin{array}{l}\text { 3. Kesesuaian item-item instrumen dengan indikator: } \\
\text { Tanggung Jawab }\end{array}$ & 8 & & $\sqrt{ }$ \\
\hline & $\begin{array}{l}\text { 4. Kecukupan item-item instrumen dalam menilai tanggung } \\
\text { jawab mahasiswa }\end{array}$ & 8 & & $\sqrt{ }$ \\
\hline \multirow[t]{3}{*}{ C. } & Indikator: Displin Diri & & & \\
\hline & $\begin{array}{l}\text { 5. Kesesuaian item-item instrumen dengan indikator: disiplin } \\
\text { diri }\end{array}$ & 9 & & $\sqrt{ }$ \\
\hline & $\begin{array}{l}\text { 6. Kecukupan item-item instrumen dalam menilai disiplin } \\
\text { diri mahasiswa }\end{array}$ & 8 & & $\sqrt{ }$ \\
\hline \multirow[t]{3}{*}{ D. } & Indikator: Kegigihan & & & \\
\hline & $\begin{array}{l}\text { 7. Kesesuaian item-item instrumen dengan indikator: } \\
\text { kegigihan }\end{array}$ & 9 & & $\sqrt{ }$ \\
\hline & $\begin{array}{l}\text { 8. Kecukupan item-item instrumen dalam menilai kegigihan } \\
\text { mahasiswa }\end{array}$ & 8 & & $\sqrt{ }$ \\
\hline \multirow[t]{3}{*}{ E. } & Indikator: Apresiasi terhadap Kebhinekaan & & & \\
\hline & $\begin{array}{l}\text { 9. Kesesuaian item-item instrumen dengan indikator: } \\
\text { apresiasi terhadap kebhinekaan }\end{array}$ & 9 & & $\sqrt{ }$ \\
\hline & $\begin{array}{l}\text { 10. Kecukupan item-item instrumen dalam menilai apresiasi } \\
\text { terhadap kebhinekaan mahasiswa }\end{array}$ & 9 & & $\sqrt{ }$ \\
\hline \multirow[t]{3}{*}{ F. } & Indikator: Semangat Berkontribusi & & & \\
\hline & $\begin{array}{l}\text { 11. Kesesuaian item-item instrumen dengan indikator: } \\
\text { semangat berkontribusi }\end{array}$ & 10 & & $\sqrt{ }$ \\
\hline & $\begin{array}{l}\text { 12. Kecukupan item-item instrumen dalam menilai semangat } \\
\text { berkontribusi mahasiswa }\end{array}$ & 9 & & $\sqrt{ }$ \\
\hline
\end{tabular}

Data yang diperoleh dari kegiatan validasi ahli evaluasi terhadap instrumen evaluasi, ditunjukkan dalam tabel 4 berikut:

Tabel 4. Data Validasi Ahli Evaluasi

\begin{tabular}{clcc}
\hline No. & \multicolumn{1}{c}{ Aspek yang Dinilai } & Nilai & Kategori \\
\hline 1. & Kejelasan petunjuk menjawab & 9 & Sangat Baik \\
2. & Kejelasan item-item & 8 & Sangat Baik \\
3. & Jumlah item & 9 & Sangat Baik \\
4. & Kejelasan petunjuk penyekoran & 9 & Sangat Baik \\
5. & Ketepatan kategori skor & 9 & Sangat Baik \\
\hline \multicolumn{2}{r}{ Rata-Rata } & $\mathbf{8 , 8}$ & Sangat Baik \\
\hline
\end{tabular}

Setelah diperoleh data validasi ahli evaluasi, selanjutnya dilakukan revisi terhadap draft instrumen evaluasi karakter. Berikut ini tabel dari revisi data validasi ahli evaluasi yang telah dilakukan. 
Tabel 5. Revisi Berdasarkan Data Validasi Ahli Evaluasi

\begin{tabular}{|c|c|c|c|c|}
\hline \multirow[t]{2}{*}{ No. } & \multirow{2}{*}{ Aspek yang Dinilai } & \multirow{2}{*}{ Nilai } & \multicolumn{2}{|c|}{ Revisi } \\
\hline & & & Ya & Tidak \\
\hline 1. & Kejelasan petunjuk menjawab & 9 & & $\sqrt{ }$ \\
\hline 2. & Kejelasan item-item & 8 & & $\sqrt{ }$ \\
\hline 3. & Jumlah item & 9 & & $\sqrt{ }$ \\
\hline 4. & Kejelasan petunjuk penyekoran & 9 & & $\sqrt{ }$ \\
\hline 5. & Ketepatan kategori skor & 9 & & $\sqrt{ }$ \\
\hline
\end{tabular}

Berdasarkan tabel di atas hasil data validasi oleh ahli evaluasi bahwa tidak ada revisi terhadap draft instrumen evaluasi karakter yang peneliti kembangkan. Selanjutnya peneliti melakukan validasi dengan ahli bahasa indonesia terhadap instrumen evaluasi karakter untuk mahasiswa/i program pendidikan guru pendidikan anak usia dini yang dikembangkan. Berikut ini tabel data validasi dari ahli Bahasa Indonesia.

Tabel 6. Data Validasi Ahli Bahasa Indonesia

\begin{tabular}{clcc}
\hline No. & \multicolumn{1}{c}{ Aspek yang Dinilai } & Nilai & Kategori \\
\hline 1. & Pilihan kata & 9 & Sangat Baik \\
2. & Kejelasan item pernyataan & 8 & Sangat Baik \\
3. & Ketepatan teknik penulisan & 9 & Sangat Baik \\
4. & Penggunaan bahasa Indonesia baku & 9 & Sangat Baik \\
\hline \multicolumn{2}{r}{ Rata-Rata } & $\mathbf{8 , 8}$ & Sangat Baik \\
\hline
\end{tabular}

Berdasarkan tabel di atas bahwa validasi oleh ahli Bahasa Indonesia endapatkan nilai rata-rata 8,8 dengan kategori sangat baik. Selanjutnya dilakukan revisi terhadap draft instrumen evaluasi karakter mahasiswa program pendidikan guru pendidikan anak usia dini. Berikut ini tabel revisi berdasarkan data validasi oleh ahli Bahasa Indonesia.

Tabel 7. Revisi Berdasarkan Data Validasi Ahli Bahasa Indonesia

\begin{tabular}{llcc}
\hline No. & \multicolumn{1}{c}{ Aspek yang Dinilai } & Nilai & \multicolumn{2}{c}{ Revisi } \\
& & 9 & Tidak \\
\hline 1. & Pilihan kata & 8 & $\sqrt{ }$ \\
2. & Kejelasan item pernyataan & 9 & $\sqrt{ }$ \\
3. & Ketepatan teknik penulisan & 9 & $\sqrt{ }$ \\
4. & Penggunaan bahasa Indonesia baku & 9 & $\sqrt{ }$ \\
\hline
\end{tabular}

Berdasarkan tabel di atas dapat disimpulkan bahwa tidak ada revisi dari validasi oleh ahli Bahasa Indonesia. Selanjutnya peneliti beralih pada langkah IV yaitu uji coba lapangan skala kecil dan revisi produk. Kegiatan ini di awali dengan pengembangan instrumen uji coba produk, yang dilanjutkan dengan uji coba kelompok kecil yang dilakukan oleh 20 orang mahasiswa pendidikan guru pendidikan anak usia dini di Universitas Negeri Gorontalo yang mewakili angkatan pada tahun ajaran 2019/2020, 2018/2019, 2017/2018, 2016/2017. Uji lapangan skala kecil dilakukan untuk menilai keterbacaan kata-kata/kalimat dalam instrumen. Berikut ini tabel data hasil uji coba lapangan skala kecil. 
Tabel 8. Data Uji Coba Lapangan Skala Kecil

\begin{tabular}{|c|c|c|c|c|c|c|c|c|c|c|c|c|}
\hline \multirow{2}{*}{ No } & \multirow{2}{*}{ Pernyataan } & \multicolumn{11}{|c|}{ Persentase (\%) Penilaian } \\
\hline & & 0 & 1 & 2 & 3 & 4 & 5 & 6 & 7 & 8 & 9 & 10 \\
\hline \multirow[t]{5}{*}{$\mathbf{A}$} & Indikator: Kejujuran & & & & & & & & & & & \\
\hline & 1. Keterbacaan huruf & 0 & 0 & 0 & 0 & 0 & 0 & 0 & 0 & 0 & 0 & 100 \\
\hline & 2. Keterbacaan kalimat & 0 & 0 & 0 & 0 & 0 & 0 & 0 & 0 & 0 & 0 & 100 \\
\hline & 3. Kejelasan petunjuk & 0 & 0 & 0 & 0 & 0 & 0 & 0 & 0 & 0 & 0 & 100 \\
\hline & 4. Kejelasan pernyataan & 0 & 0 & 0 & 0 & 0 & 0 & 0 & 0 & 10 & 90 & 0 \\
\hline \multirow[t]{5}{*}{ B } & $\begin{array}{l}\text { Indikator: Tanggung } \\
\text { Jawab }\end{array}$ & & & & & & & & & & & \\
\hline & 5. Keterbacaan huruf & 0 & 0 & 0 & 0 & 0 & 0 & 0 & 0 & 0 & 0 & 100 \\
\hline & 6. Keterbacaan kalimat & 0 & 0 & 0 & 0 & 0 & 0 & 0 & 0 & 0 & 0 & 100 \\
\hline & 7. Kejelasan petunjuk & 0 & 0 & 0 & 0 & 0 & 0 & 0 & 0 & 0 & 0 & 100 \\
\hline & 8. Kejelasan pernyataan & 0 & 0 & 0 & 0 & 0 & 0 & 0 & 0 & 10 & 90 & 0 \\
\hline \multirow[t]{5}{*}{ C. } & Disiplin Diri & & & & & & & & & & & \\
\hline & 9. Keterbacaan huruf & 0 & 0 & 0 & 0 & 0 & 0 & 0 & 0 & 0 & 0 & 100 \\
\hline & 10. Keterbacaan kalimat & 0 & 0 & 0 & 0 & 0 & 0 & 0 & 0 & 0 & 0 & 100 \\
\hline & 11. Kejelasan petunjuk & 0 & 0 & 0 & 0 & 0 & 0 & 0 & 0 & 0 & 0 & 100 \\
\hline & 12. Kejelasan pernyataan & 0 & 0 & 0 & 0 & 0 & 0 & 0 & 0 & 5 & 95 & 0 \\
\hline \multirow[t]{5}{*}{ D. } & Kegigihan & & & & & & & & & & & \\
\hline & 13. Keterbacaan huruf & 0 & 0 & 0 & 0 & 0 & 0 & 0 & 0 & 0 & 0 & 100 \\
\hline & 14. Keterbacaan kalimat & 0 & 0 & 0 & 0 & 0 & 0 & 0 & 0 & 0 & 0 & 100 \\
\hline & 15. Kejelasan petunjuk & 0 & 0 & 0 & 0 & 0 & 0 & 0 & 0 & 0 & 0 & 100 \\
\hline & 16. Kejelasan pernyataan & 0 & 0 & 0 & 0 & 0 & 0 & 0 & 0 & 0 & 0 & 100 \\
\hline \multirow[t]{5}{*}{ E. } & $\begin{array}{l}\text { Apresiasi terhadap } \\
\text { kebhinekaan }\end{array}$ & & & & & & & & & & & \\
\hline & 17. Keterbacaan huruf & 0 & 0 & 0 & 0 & 0 & 0 & 0 & 0 & 0 & 0 & 100 \\
\hline & 18. Keterbacaan kalimat & 0 & 0 & 0 & 0 & 0 & 0 & 0 & 0 & 0 & 0 & 100 \\
\hline & 19. Kejelasan petunjuk & 0 & 0 & 0 & 0 & 0 & 0 & 0 & 0 & 0 & 0 & 100 \\
\hline & 20. Kejelasan pernyataan & 0 & 0 & 0 & 0 & 0 & 0 & 0 & 0 & 5 & 95 & 0 \\
\hline \multirow[t]{5}{*}{ F. } & Semangat berkontribusi & & & & & & & & & & & \\
\hline & 21. Keterbacaan huruf & 0 & 0 & 0 & 0 & 0 & 0 & 0 & 0 & 0 & 0 & 100 \\
\hline & 22. Keterbacaan kalimat & 0 & 0 & 0 & 0 & 0 & 0 & 0 & 0 & 0 & 0 & 100 \\
\hline & 23. Kejelasan petunjuk & 0 & 0 & 0 & 0 & 0 & 0 & 0 & 0 & 0 & 0 & 100 \\
\hline & 24. Kejelasan pernyataan & 0 & 0 & 0 & 0 & 0 & 0 & 0 & 0 & 0 & 0 & 100 \\
\hline
\end{tabular}

Berdasarkan data uji coba lapangan skala kecil, maka dapat disimpulkan bahwa tidak perlu dilakukan revisi terhadap semua aspek yang dinilai dalam evaluasi karakter. Evaluasi karakter ini dapat diterapkan pada mahasiswa/i program pendidikan anak usia dini dengan tujuan agar pendidik anak usia dini mempunyai modal karakter baik untuk anak. Karena anak usia dini merupakan anak yang meniru atau mengcopy apapun yang dilakukan oleh guru. Untuk itu, pendidikan karakter pada calon guru anak usia dini sangat perlu untuk membentuk generasi yang memiliki moral dan nilai-nilai etika yang baik dalam lingkungan masyarakat.

Berbagai upaya pendidikan karakter bagi mahasiswa yang telah dilakukan akan menjadi tidak bermakna jika tidak dievaluasi bagaimana dampaknya terhadap perubahan karakter mahasiswa/i program PG PAUD. Apakah perubahan karakter itu menjadi lebih baik, atau sebaliknya bertambah jelek, atau tidak ada perubahan sama sekali. Dengan kata lain, dibutuhkan evaluasi terhadap dampak pendidikan karakter yang telah dilakukan bagi perubahan karakter mahasiswa. Untuk kepentingan evaluasi dimaksud, maka dibutuhkan instrumen khusus untuk menilai perubahan atau perkembangan karakter tersebut, khususnya karakter mahasiswa.

Hasil penelitian dan pengembangan ini telah menghasilkan instrumen evaluasi karakter bagi mahasiswa/i program PG PAUD yang telah divalidasi ahli, dan telah melalui uji kelompok kecil. Validasi ahli dilakukan oleh ahli evaluasi, ahli pendidikan karakter, dan 
ahli bahasa Indonesia. Data hasil validasi ahli diperoleh dalam bentuk data kuantitatif dan data kualitatif, di mana hasil dari analisis data tersebut telah digunakan untuk merevisi aspek-aspek yang belum memenuhi syarat sesuai penilaian para ahli.

Validasi ahli dalam kegiatan penelitian dan pengembangan (Research and Development) merupakan salah satu langkah penting yang harus dilalui. Berbagai metode penelitian dan pengembangan yang dikemukakan oleh para ahli, selalu menyertakan validasi ahli sebagai salah satu langkah yang harus dilalui oleh seseorang yang melakukan penelitian dan pengembangan. Jika dicermati, hal ini dilakukan dengan pertimbangan bahwa sebuah produk yang dihasilkan dari sebuah penelitian dan pengembangan harus memiliki ketepatan (validitas) dari berbagai aspek, seperti aspek keilmuan, aspek model (jika produk itu berupa model), aspek bahasa, dan aspek desain. Dengan demikian, maka dapat dikatakan bahwa jika sebuah produk yang telah divalidasi oleh para ahli, berarti produk hasil penelitian dan pengembangan tersebut telah dapat dipertanggungjawabkan dari segi keilmuan, dari segi bahasa, dari segi model (jika produk itu berupa model), dan dari segi desain.

Validitas merupakan ukuran sebuah instrumen atau produk yang menunjukkan instrumen atau produk tersebut telah dianggap valid atau tepat untuk digunakan. Validitas dari kata Inggris valid yang berarti tepat, validity yang berarti ketepatan. Kata valid diadaptasi ke dalam bahasa Indonesia dengan istilah sahih, dan istilah validitas menjadi kesahihan. Istilah validitas digunakan dalam bidang evaluasi. Menurut Anastasi \& Urbina (1997) validitas tes menyangkut apa yang diukur oleh tes dan seberapa baik tes itu bisa mengukur. Vaditas tes memberi tahu tentang apa yang bisa disimpulkan dari skor-skor tes. Sebagaimana Shepard (Wolming \& Wikström, 2010) memiliki pendapat yang sama bahwa validitas berkaitan dengan evaluasi yang tepat. Dimyati \& Mudjiono (2009) mengartikan validitas atau kesahihan sebagai ketepatan evaluasi mengevaluasi apa yang seharusnya dievaluasi. Arikunto (1990) menguraikan bahwa kesahihan instrument evaluasi diperoleh melalui hasil pemikiran dan dari hasil pengalaman. Dari dua cara tersebut diperoleh empat macam kesahihan, yakni: kesahihan isi (content validity), kesahihan konstruksi (contruction validity), kesahihan yang ada sekarang (concurrent validity), dan kesahihan prediksi (prediction validity).

Mengacu pada penjelasan validitas tersebut, maka dapat dikatakan instrumen karakter yang dikembangkan melalui penelitian ini telah dapat dipertanggunjawabkan dari segi materi isi pertanyaan/pertanyaan, dan konstruk pertanyaan/pernyataan. Oleh sebab itu instrumen ini telah dapat digunakan pada subyek dan konteks yang telah ditetapkan, atau konteks lain yang memiliki karakteristik yang sama dengan konteks yang telah ditetapkan tersebut.

Berdasarkan analisis data hasil uji lapangan kelompok kecil diperoleh kesimpulan bahwa instrumen karakter yang telah diuji cobakan tidak memerlukan revisi, dalam arti kata-kata atau kalimat dalam instrumen tersebut dapat dan mudah dibaca oleh pengguna instrumen. Pengguna instrumen tersebut jika disandingkan dengan instrumen tes disebut testee (peserta tes, dalam hal ini mahasiswa). Kemudahan dalam membaca dan memahami kata, kalimat, dan maksud pertanyaan atau pernyataan sebuah instrumen tentu saja akan memberikan kenyamanan bagi pengguna/testee dalam memberikan jawaban yang diharapkan. Sebaliknya kesulitan dalam membaca dan memahami kata, kalimat,dan maksud pertanyaan atau pernyataan sebuah instrumen dikhawatirkan akan menimbulkan ketidaknyamanan, kesulitan bahkan kecemasan pada pihak pengguna/testee. Anastasi \& Urbina (1997) menyimpulkan bahwa kecemasan peserta tes (testee) turut mempengaruhi kinerjanya dalam menyelesaikan tes dan selanjutnya berdampak pada hasil tes. Sedikit kecemasan memberikan dampak yang baik, sementara kecemasan yang tinggi bersifat membahayakan. 
Bertitik tolak dari hasil validasi ahli dan uji lapangan kelompok kecil, maka dapat disimpulkan bahwa instrumen karakter mahasiswa/i program pendidikan guru pendidikan anak usia dini di Universitas Negeri Gorontalo ini merupakan instrumen yang telah memenuhi syarat validitas, dan telah memenuhi syarat kemudahan. Dengan demikian, instrumen ini telah layak digunakan untuk mengevaluasi karakter mahasiswa/i program PG PAUD. Namun demikian masih dibutuhkan penelitian lanjutan untuk mengetahui tingkat validitas dan reliabilitas instrumen ini.

Instrumen yang dihasilkan ini berupa angket evaluasi karakter mahasiswa. Instrumen ini meliputi: (1) pengantar, bagian ini menjelaskan maksud dari pada instrument tersebut, (2) petunjuk pengerjaan, bagian ini memberikan penjelasan tentang cara memberikan jawaban terhadap pertanyaan dan pernyataan dalam instrument tersebut, (3) pertanyaan/pernyataan, bagian ini berisi pernyataan-pernyataan untuk mengukur karakter, yang dijabarkan dari indikator karakter, yakni (a) kejujuan, (b) rasa tanggung jawab, (c) semangat belajar, (d) disiplin diri, (e) kegigihan, (f) apresiasi terhadap kebhinekaan, (g) semangat berkontribusi, dan (h) optimisme, (4) pedoman penyekoran, yang menjelaskan tentang cara memberikan skor pada setiap item, baik pada item positif dan item negatif, dan kategori penilaian, yang menjelaskan tentang penetapan kategori karakter berdasarkan perolehan skor masing-masing testee.

\section{SIMPULAN}

Berdasarkan hasil penelitian dan pengembangan diperoleh kesimpulan sebagai berikut: (a) telah tersusun instrumen evaluasi karakter mahasiswa/i program pendidikan guru pendidikan anak usia dini yang telah melalui validasi ahli, yakni: ahli pendidikan karakter, ahli evaluasi, dan ahli bahasa Indonesia. Instrumen evaluasi karakter mahasiswa tersebut telah pula diuji cobakan melalui uji coba lapangan kelompok kecil, (b) instrumen evaluasi karakter mahasiswa yang merupakan hasil penelitian dan pengembangan ini, telah layak digunakan untuk mengevaluasi karakter mahasiswa/i program pendidikan guru pendidikan anak usia dini di Universitas Negeri Gorontalo setelah memperoleh pembinaan karakter. Oleh sebab itu, disarankan agar instrumen ini digunakan untuk mengevaluasi karakter mahasiswa/i program pendidikan guru pendidikan anak usia dini di Universitas Negeri Gorontalo, agar berbagai upaya pembinaan karakter yang telah dilakukan dapat diketahui dengan jelas dampaknya bagi pengembangan karakter mahasiswa/i program pendidikan guru pendidikan usia dini di Universitas Negeri Gorontalo.

\section{UCAPAN TERIMAKASIH}

Terimakasih Kepada pihak terkait dalam penelitian ini yaitu Universitas Negeri Gorontalo, validator ahli Bahasa Indonesia, Validator ahli pendidikan karakter, validator ahli evaluasi, serta pihak-pihak yang tidak bisa peneliti sebutkan satu-persatu.

\section{DAFTAR PUSTAKA}

Anastasi, A., \& Urbina, S. (1997). Psychological Testing. Prentice-Hall, Inc.

Arikunto, S. (1990). Dasar-Dasar Evaluasi Pendidikan. Bumi Aksara.

Borg, \& Gall, M. (1983). Educational research an introduction (fourth edition). New York: Longman.

Brownlee, J., Purdie, N., \& Boulton-Lewis, G. (2001). Changing Epistemological Beliefs in Pre-service Teacher Education Students. Teaching in Higher Education, 6(2), 247-268. https:/ / doi.org/10.1080/13562510120045221

Buehl, M. M., \& Alexander, P. A. (2001). Beliefs about Academic Knowledge. Educational Psychology Review, 13(4), 385-418. https:/ / doi.org/10.1023/ A:1011917914756

Dimyati, T. R. (2018). Pembentukan Karakter Mahasiswa Dalam Sistem Pendidikan Tinggi $\begin{array}{lllll}\text { Islam. TADRIS: Jurnal Pendidikan Islam, } & 17 .\end{array}$ 
https://doi.org/10.19105/tjpi.v13i1.1716

Dimyati, \& Mudjiono. (2009). Belajar dan Pembelajaran. Rineka Cipta.

Fika, Y., Meilanie, S. M., \& Fridani, L. (2019). Peningkatan Kemampuan Bicara Anak melalui Bermain Peran Berbasis Budaya. Jurnal Obsesi : Jurnal Pendidikan Anak Usia Dini, 4(1), 50. https:// doi.org/10.31004/obsesi.v4i1.229

Ghufron, A. (2012). Anik Ghufron Desain Pendidikan Karakter. 1, 99-110.

Isikoglu, N. (2008). The effects of a teaching methods course on early childhood preservice teachers' beliefs. Journal of Early Childhood Teacher Education, 29(3), 190-203. https://doi.org/10.1080/10901020802275260

Kemendiknas. (2011). Panduan Pendidikan Karakter. Badan Penelitian dan Pengembangan Pusat Kurikulum dan Perbukuan.

Kurdi, M. S. (2018). Evaluasi Implementasi Desain Pendidikan Karakter Berbasis Pendekatan Humanistik. Elementary: Jurnal Ilmiah Pendidikan Dasar, 4(2), 125. https://doi.org/10.32332/elementary.v4i2.1243

Maiza, Z., \& Nurhafizah, N. (2019). Pengembangan Keprofesian Berkelanjutan dalam Meningkatkan Profesionalisme Guru Pendidikan Anak Usia Dini. Jurnal Obsesi : Jurnal Pendidikan Anak Usia Dini, 3(2), 356. https:/ / doi.org/10.31004/obsesi.v3i2.196

Majid, R. A., Ali, M. M., \& Alias, A. (2014). Teacher character strengths and talent development. International Education Studies, 7(13), 175-183. https://doi.org/10.5539/ies.v7n13p175

Mei-Ju, C., Chen-Hsin, Y., \& Pin-Chen, H. (2014). The Beauty of Character Education on Preschool Children's Parent-child Relationship. Procedia - Social and Behavioral Sciences, 143, 527-533. https://doi.org/10.1016/j.sbspro.2014.07.431

Mischo, C., Wahl, S., Strohmer, J., \& Wolf, C. (2013). Does Early Childhood Teacher Education Affect Students' Cognitive Orientations? Journal of Education and Training Studies, 2(1), 193-206. https:/ / doi.org/10.11114/jets.v2i1.206

Nuraeni, L., Andrisyah, A., \& Nurunnisa, R. (2019). Efektivitas Program Sekolah Ramah Anak dalam Meningkatkan Karakter Anak Usia Dini. Jurnal Obsesi : Jurnal Pendidikan Anak Usia Dini, 4(1), 20. https:// doi.org/10.31004/obsesi.v4i1.204

Raka, G. (2011). Pendidikan Karakter di Sekolah: dari Gagasan ke Tindakan. PT Alex Media Komputindo.

Rodríguez, L., \& Cano, F. (2006). The epistemological beliefs, learning approaches and study orchestrations of university students. Studies in Higher Education, 31(5), 617-636. https://doi.org/10.1080/03075070600923442

Srianita, Y., Akbar, M., \& Meilanie, S. M. (2019). Pembentukan Karakter dalam Pendidikan Makan (Studi Kasus di Raudhatul Athfal Istiqlal Jakarta). Jurnal Obsesi : Jurnal Pendidikan Anak Usia Dini, 4(1), 152. https:/ / doi.org/10.31004/obsesi.v4i1.277

Susanti, R. (2013). Penerapan Pendidikan Karakter Di Kalangan Mahasiswa. AL-Ta Lim, 20(3), 480. https:// doi.org/10.15548/jt.v20i3.46

Tanto, O. D., Hapidin, H., \& Supena, A. (2019). Penanaman Karakter Anak Usia Dini dalam Kesenian Tradisional Tatah Sungging. Jurnal Obsesi : Jurnal Pendidikan Anak Usia Dini, 3(2), 337. https:// doi.org/10.31004/obsesi.v3i2.192

Veziroglu-Celik, M., \& Acar, I. H. (2018). Teaching Approaches and Practices of Student Teachers in Early Childhood Education: A Convergent Mixed Methods Study. Journal of Education and Training Studies, 6(11), 234. https://doi.org/10.11114/jets.v6i11.3634

Wolming, S., \& Wikström, C. (2010). The concept of validity in theory and practice. Assessment in Education: Principles, Policy and Practice, 17(2), 117-132. https://doi.org/10.1080/09695941003693856 